\title{
ZROZUMIEĆ WALIJCZYKÓW W ICH POLITYCZNYCH DECYZJACH
}

\author{
TO UNDERSTAND THE WELSH IN THEIR \\ POLITICAL DECISIONS
}

\begin{abstract}
Brexit is one of the most important events that dominated the media discourse in 2017. The decision of the residents of the United Kingdom to leave the EU structures will certainly have not only serious economic consequences, but also political, social and cultural ones, both for the United Kingdom itself and for residents of countries that will stay in the European Union.

While analysing the results of the referendum, which took place on $23^{\text {rd }}$ June 2016, it can be seen that the majority of voters in England and Wales voted in favour of leaving the European Union, while those in Scotland and Northern Ireland supported the United Kingdom remaining in the EU structures.

The aim of the article is to explain why the majority of voters in Wales were in favour of the United Kingdom exit from the European Union and to indicate potential benefits or losses resulting from the decision taken.
\end{abstract}

Key words: Brexit; Wales; referendum; political preferences; national identity

\section{Streszczenie}

Brexit jest jednym z tych wydarzeń, które zdominowały dyskurs medialny w 2017 roku. Decyzja mieszkańców Zjednoczonego Królestwa o opuszczeniu struktur unijnych będzie miała z pewnością poważne konsekwencje nie tylko ekonomiczne, o których mówi się najwięcej, ale również polityczne, społeczne i kulturowe, zarówno dla samego Zjednoczonego Królestwa, jak i mieszkańców państw, które pozostaną członkami Unii Europejskiej.
GRZEGORZ LIBOR Uniwersytet Śląski, Katowice E-mail: grzegorz.libor@us.edu.pl

CITATION: Libor, G. (2018). Zrozumieć Walijczyków w ich politycznych decyzjach. Sprawy Narodowościowe. Seria nowa, 2018(50). https://doi.org/10.11649/sn.1687

This work was supported by the author's own resources. No competing interests have been declared.

This is an Open Access article distributed under the terms of the Creative Commons Attribution 3.0 PL License (creativecommons.org/licenses/by/3.0/pl/), which permits redistribution, commercial and non-commercial, provided that the article is properly cited. (C) The Author(s) 2018.

Publisher: Institute of Slavic Studies, Polish Academy of Sciences 
Analizując wyniki referendum, do którego doszło 23 czerwca 2016 roku, dostrzec można, że za wyjściem z Unii Europejskiej opowiedziała się większość głosujących w Anglii i Walii, podczas gdy wyborcy w Szkocji oraz Irlandii Północnej optowali za pozostaniem Zjednoczonego Królestwa w strukturach unijnych.

Celem artykułu jest próba wyjaśnienia, dlaczego większość głosujących na terenie Walii opowiedziała się za wyjściem Zjednoczonego Królestwa z Unii Europejskiej oraz wskazanie potencjalnych korzyści lub też strat wynikających z podjętej decyzji.

Stowa kluczowe: Brexit; Walia; referendum; preferencje polityczne; tożsamość narodowa

\section{WPROWADZENIE}

lednym z celów badań naukowych prowadzonych w socjologii jest, oprócz eksploracji i opisu, wyjaśnienie, w czasie którego badacze starają się odpowiedzieć na pytanie o związki przyczynowo-skutkowe występujące pomiędzy analizowanymi zdarzeniami. (Babbie, 2008) Wiele z nich wciąż wymaga wyjaśnienia. Pojawiają się również nowe, które oczekują naukowej interpretacji. Do tego typu wydarzeń, które z pewnością nadal oczekują - ze względu na swoją złożoność i aktualność - szczegółowej refleksji, zaliczyć można decyzję władz Zjednoczonego Królestwa Wielkiej Brytanii i Irlandii Północnej o opuszczeniu struktur Unii Europejskiej. Podstawą do jej podjęcia był wynik referendum z 23 czerwca 2016 roku. O ile rozkład głosów w przypadku Anglii, Szkocji i Irlandii Północnej był łatwy do przewidzenia, o tyle sporym zaskoczeniem był wynik referendum w Walii. W opinii wielu zewnętrznych obserwatorów istniała duża szansa na to, aby Walijczycy opowiedzieli się za pozostaniem Zjednoczonego Królestwa w Unii Europejskiej w związku z korzyściami, na jakie mogą liczyć dzięki członkostwu w Unii. Walia otrzymuje około 680 milionów funtów rocznie, z czego ponad 200 milionów to środki przyznawane w ramach wspólnej polityki rolnej. W ciągu ostatnich 18 lat Walia otrzymała dodatkowo ponad 4 miliardy funtów z funduszy strukturalnych. Wśród najbardziej znanych projektów zrealizowanych ze środków unijnych wymienić można między innymi: przebudowę drogi Heads of the Valleys o wartości 79 milionów funtów oraz rewitalizację centrów Merthyr Tydfil, Pontypridd oraz Llanelli. Począwszy od 2000 roku z funduszy strukturalnych Walii przyznano ponad 4 miliardy funtów. Dzięki wsparciu z Unii Europejskiej ponad 229 tysięcy mieszkańców Walii podniosło swoje kwalifikacje zawodowe (7\% populacji), stworzono ponad 36 tysięcy nowych miejsc pracy, a także zarejestrowano ponad 11 tysięcy nowych przedsiębiorstw. Terytorium Walii podzielone zostało na dwa obszary alokacji środków unijnych, tj. Wschodnią Walię oraz Zachodnią Walię i Doliny, które zaliczane są do jednych z najbardziej ubogich regionów w całej Unii Europejskiej. Do Zachodniej Walii i Dolin nie zalicza się jednak Cardiff, Flintshire, Monmouthshire, Newport, Powys, Vale of Glamorgan i Wrexham. W ogólnym rozrachunku Walia otrzymuje 245 milionów funtów więcej, aniżeli wynosi jej wkład do budżetu unijnego (Rhys, 2017). Mimo to nie brakuje w Walii głosów krytycznie odnoszących się do wsparcia uzyskiwanego z funduszy europejskich. Otóż, kiedy w 2014 roku rząd walijski z dumą ogłosił pozyskanie kolejnej puli środków unijnych, zwłaszcza dla Zachodniej Walii i Dolin, część komentatorów i polityków uznała to za porażkę. Ich zdaniem przyznanie nowej puli środków w wysokości ponad 2 miliardów funtów stanowiło jedynie dowód na to, że przyznane do tej pory środki nie poprawiły sytuacji społeczno-ekonomicznej tych regionów względem pozostałych obszarów Unii Europejskiej. Za wzór dla rozwoju Walii podawać zaczęto Finlandię, która podobnie jak Walia, położona 
jest na peryferiach Unii Europejskiej, jej mieszkańcy posługują się równie mało zrozumiatym dla innych językiem, zasoby naturalne Finlandii nie są imponujące, a mimo to standard życia jest wyższy niż w Walii (Williamson, 2014).

Celem artykułu jest próba wyjaśnienia, dlaczego większość głosujących na terenie Walii opowiedziała się za wyjściem Zjednoczonego Królestwa z Unii Europejskiej. W pierwszej części przedstawiono wyniki referendum przeprowadzonego na terenie Walii po to, aby w kolejnych podjąć próbę wyjaśnienia decyzji wyborczych osób w nich uczestniczących. W ostatniej części artykułu przedstawiono to, czego tak naprawdę zabrakło w debacie towarzyszącej referendum, a mianowicie refleksji nad faktycznymi konsekwencjami ewentualnego wyjścia Walii z Unii Europejskiej.

\section{REFERENDUM I JEGO WYNIK}

W referendum wzięło udział 33551983 wyborców z 46501241 uprawnionych do głosowania, co oznaczało frekwencję na poziomie 72,2\%. Najwyższą frekwencję odnotowano w Anglii (73\%) i Walii (71,7\%), najmniejszą w Szkocji $(67,2 \%)$ oraz Irlandii Północnej (62,7\%). 51,9\% głosujących opowiedziało się za wyjściem Zjednoczonego Królestwa z Unii Europejskiej, podczas gdy 48,1\% chciało jego pozostania w strukturach unijnych. Najwięcej zwolenników opuszczenia Unii Europejskiej było w Anglii, najmniej w Szkocji (Tab. 1).

Tabela 1. Wyniki referendum - Zjednoczone Królestwo (2016)

\begin{tabular}{|l|c|c|}
\hline & Za opuszczeniem UE & Przeciwko opuszczeniu UE \\
\hline Anglia & $53,4 \%$ & $46,6 \%$ \\
\hline Walia & $\mathbf{5 2 , 5} \%$ & $\mathbf{4 7 , 5 \%}$ \\
\hline Irlandia Północna & $44,2 \%$ & $55,8 \%$ \\
\hline Szkocja & $38,0 \%$ & $62 \%$ \\
\hline
\end{tabular}

Źr ód to: Opracowanie własne na podstawie The Electoral Commission (2017)

Spośród 22 okręgów wyborczych na terenie Walii tylko 5 opowiedziało się za pozostaniem Walii w Unii Europejskiej: Cardiff, Ceredigion, Gwynedd, Monmouthshire i Vale of Glamorgan (Tab. 2). Największą frekwencje odnotowano w Powys (77\%), najniższą natomiast w Merthyr Tydfil (67\%) (The Electoral Commission, 2017).

Tabela 2. Wyniki referendum - Walia (2016)

\begin{tabular}{|l|c|c|}
\hline & Za opuszczeniem UE & Przeciwko opuszczeniu UE \\
\hline Anglesey & $50,94 \%$ & $49,06 \%$ \\
\hline Blaenau Gwent & $62,03 \%$ & $37,97 \%$ \\
\hline Bridgend & $54,64 \%$ & $45,36 \%$ \\
\hline Caerphilly & $57,63 \%$ & $42,37 \%$ \\
\hline Cardiff & $\mathbf{3 9 , 9 8 \%}$ & $\mathbf{6 0 , 0 2} \%$ \\
\hline Carmarthenshire & $53,75 \%$ & $46,25 \%$ \\
\hline
\end{tabular}




\begin{tabular}{|l|c|c|}
\hline Ceredigion & $\mathbf{4 5 , 3 7} \%$ & $\mathbf{5 4 , 6 3} \%$ \\
\hline Conwy & $53,98 \%$ & $46,02 \%$ \\
\hline Denbighshire & $54 \%$ & $46 \%$ \\
\hline Flintshire & $56,37 \%$ & $43,6 \%$ \\
\hline Gwynedd & $\mathbf{4 1 , 0 9 \%}$ & $\mathbf{5 8 , 9 1 \%}$ \\
\hline Merthyr Tydfil & $56,44 \%$ & $43,56 \%$ \\
\hline Monmouthshire & $\mathbf{4 9 , 5 6} \%$ & $\mathbf{5 0 , 4 4 \%}$ \\
\hline Neath Port Talbot & $56,84 \%$ & $43,16 \%$ \\
\hline Newport & $55,99 \%$ & $44,01 \%$ \\
\hline Pembrokeshire & $57,14 \%$ & $42,86 \%$ \\
\hline Powys & $53,74 \%$ & $46,26 \%$ \\
\hline Rhondda Cynon Taf & $53,7 \%$ & $46,7 \%$ \\
\hline Swansea & $51,51 \%$ & $48,49 \%$ \\
\hline Torfaen & $59,78 \%$ & $40,22 \%$ \\
\hline Wrexham & $59,04 \%$ & $40,96 \%$ \\
\hline Vale of Glamorgan & $\mathbf{4 9 , 2 7} \%$ & $\mathbf{5 0 , 7 3} \%$ \\
\hline
\end{tabular}

Źr ódło: Opracowanie własne na podstawie The Electoral Commission (2017)

Ceredigion i Gwynedd to okręgi położone na zachodzie Walii, podczas gdy Cardiff, Monmouthshire i Vale of Glamorgan to okręgi usytuowane w południowej lub południowo-wschodniej części kraju (Mapa 1).

Mapa 1. Podział terytorialny Walii

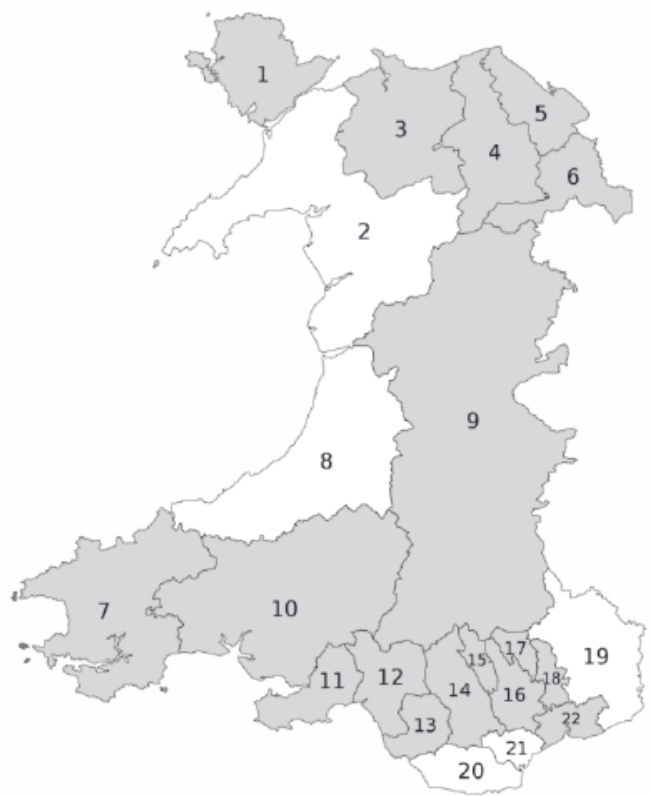




\section{Legenda}

1 - Isle of Anglesey

2 - Gwynedd

3- Conwy

4 - Denbighshire

5 - Flintshire

6-Wrexham

\section{7 - Pembrokeshire \\ 8 - Ceredigion}

9 - Powys

10 - Carmarthenshire

11 - Swansea

12 - Neath Port Talbot
13 - Bridgend

14 - Rhondda Cynon Taff

15 - Merthyr Tydil

16 - Caerphilly

17 - Blaenau Gwent

18 - Torfaen

Źr ó dło: Opracowanie własne na podstawie The Electoral Commission (2017)

19 - Monmouthshire

20 - Vale of Glamorgan

21 - Cardiff

22 - Newport

\section{W POSZUKIWANIU WYJAŚNIENIA - KONCEPCJE TOŻSAMOŚCIOWE}

Jedną z najbardziej znanych koncepcji tożsamości, która odnosi się bezpośrednio do przykładu Walii, jest koncepcja Johna Loughlina (Loughlin, 2007, ss. 35-63). Wyróżnił on cztery rodzaje tożsamości narodowej Walijczyków:

- tożsamość osób urodzonych w Walii, które deklarują znajomość języka walijskiego,

- tożsamość osób urodzonych w Walii, które nie znają języka walijskiego, a na co dzień posługują się językiem angielskim,

- tożsamość osób, które mają pochodzenie brytyjskie, lecz nie urodziły się w Walii,

- tożsamość osób niebrytyjskiego pochodzenia, zamieszkujących terytorium Walii (na przykład Polaków).

W przypadku dwóch pierwszych rodzajów tożsamości elementem różnicującym je jest rola oraz znaczenie przypisywane językowi walijskiemu, który jest przez wielu dziś traktowany jako wyznacznik bycia prawdziwym Walijczykiem oraz postrzegany jako szansa na zdobycie dobrze płatnej pracy i osiągnięcie lepszego statusu społecznego.

Przyjęcie tej perspektywy oznaczałoby, że preferencje polityczne Walijczyków można by wyjaśnić odwołując się do stopnia znajomości języka walijskiego. Zestawienie wyników referendum z podziałem terytorium Walii ze względu na znajomość języka walijskiego przez wyborców wskazuje na istnienie tego typu korelacji tylko w 2 z 5 przypadków. Jak wynika bowiem ze spisu powszechnego z 2011 roku, z największym odsetkiem osób deklarujących znajomość języka walijskiego mamy do czynienia zarówno w przypadku Ceredigion, jak i Gwynedd, ale nie tylko. To samo dotyczy innych okręgów, takich jak Carmarthenshire czy też Anglesey, tj. okręgów, których większość mieszkańców opowiedziała się za opuszczeniem Unii Europejskiej przez Zjednoczone Królestwo (Mapa 2).

Drugim elementem różnicującym mieszkańców Walii $w$ ich decyzjach politycznych jest, oprócz języka walijskiego, miejsce urodzenia. Preferencje polityczne osób urodzonych na terenie Walii lub też szerzej osób pochodzenia brytyjskiego winny różnić się od preferencji politycznych osób pochodzenia niebrytyjskiego. Niemniej jednak również i w tym przypadku trudno o wskazanie jednoznacznego związku pomiędzy miejscem urodzenia a preferencjami politycznymi mieszkańców Walii. Ponownie tylko w przypadku 2 z 5 okręgów, których mieszkańcy opowiedzieli się za pozostaniem Walii w Unii, można mówić o istnieniu tego rodzaju korelacji (Mapa 3). Do podobnych konkluzji dojść można, spoglądając na mapę ulokowania imigrantów w Walii. Większość z nich co prawda zamieszkuje Cardiff, Gwynedd i Ceredigion, a więc okręgi, które opowiedziały się za pozostaniem Zjednoczonego Królestwa w Unii Europejskiej, lecz spory odsetek zamieszkuje również tereny Wrexham, Newport czy też Swansea, a zatem okręgi, które zadeklarowały chęć opuszczenia Unii Europejskiej przez Zjednoczone Królestwo. 
Mapa 2. Deklarowana znajomość języka walijskiego
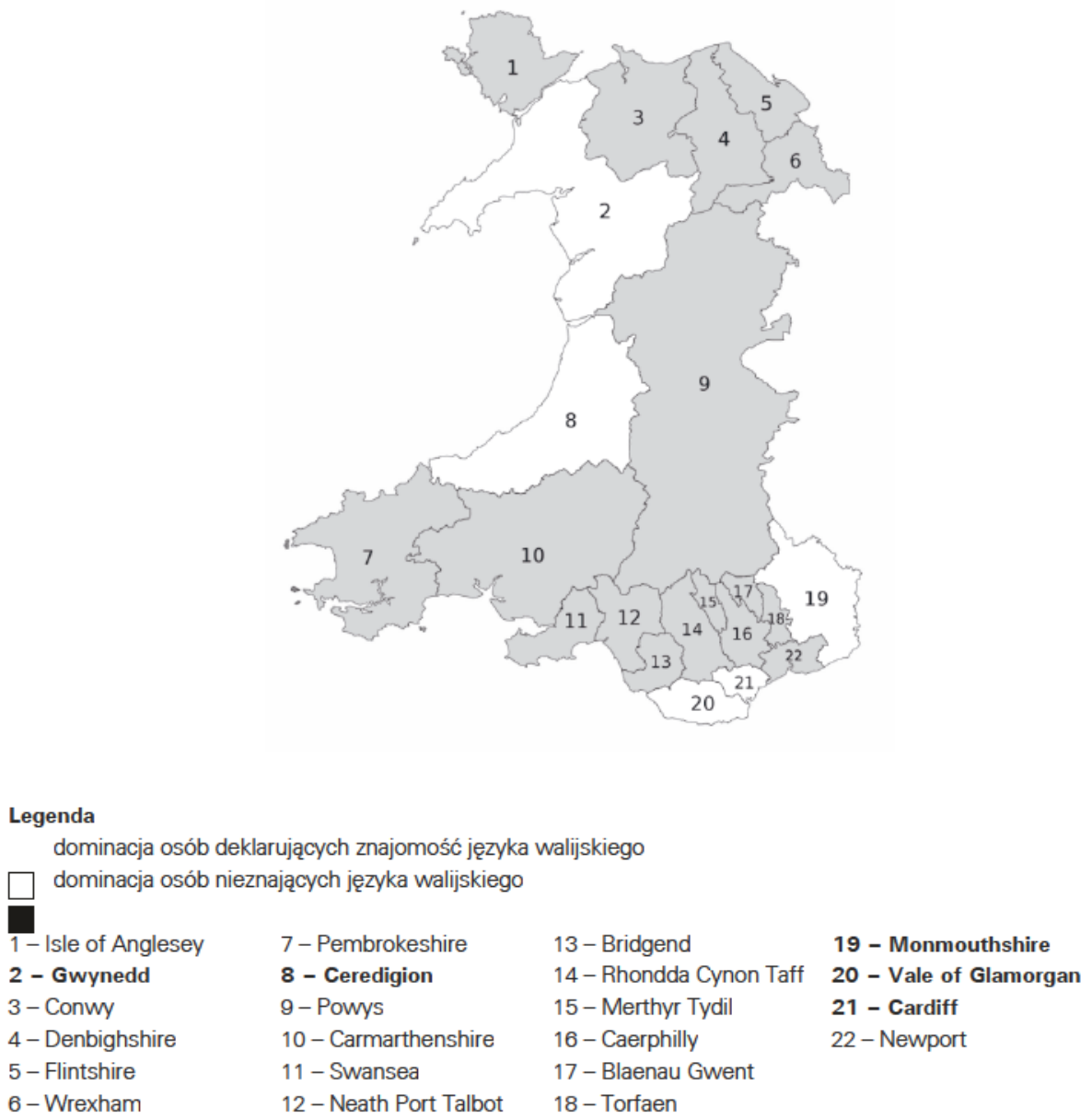

Źr ódło: Opracowanie wlasne na podstawie spisu powszechnego 2011 (ONS, 2012)

Koncepcja tożsamości narodowej autorstwa Johna Loughlina charakteryzuje się zatem niewielkimi walorami eksplikacyjnymi, jeśli chodzi o preferencje polityczne Walijczyków. Posłużenie się językiem oraz miejscem urodzenia jako czynnikami różnicującymi okazuje się niewystarczające. Zdaniem Grahama Daya, przedstawiciela hybrydowego podejścia do kwestii tożsamości narodowej Walijczyków, wynikać to może z dość silnego zróżnicowania wewnętrznego społeczeństwa walijskiego. Miejsce urodzenia czy też znajomość języka walijskiego to tak naprawdę jedynie dwa z wielu determinantów preferencji politycznych mieszkańców Walii (Day 2002). Nacjonalizm, którego symptomem w przypadku Walii jest znaczenie przypisywane językowi walijskiemu, może być zatem wyttumaczeniem decyzji politycznych mieszkańców tylko niektórych z okręgów wyborczych, takich jak Gwynedd czy też Ceredigion, lecz nie wszystkich. To samo tyczy się pozostałych czynników (m.in. miejsca urodzenia). 
Mapa 3. Miejsce urodzenia

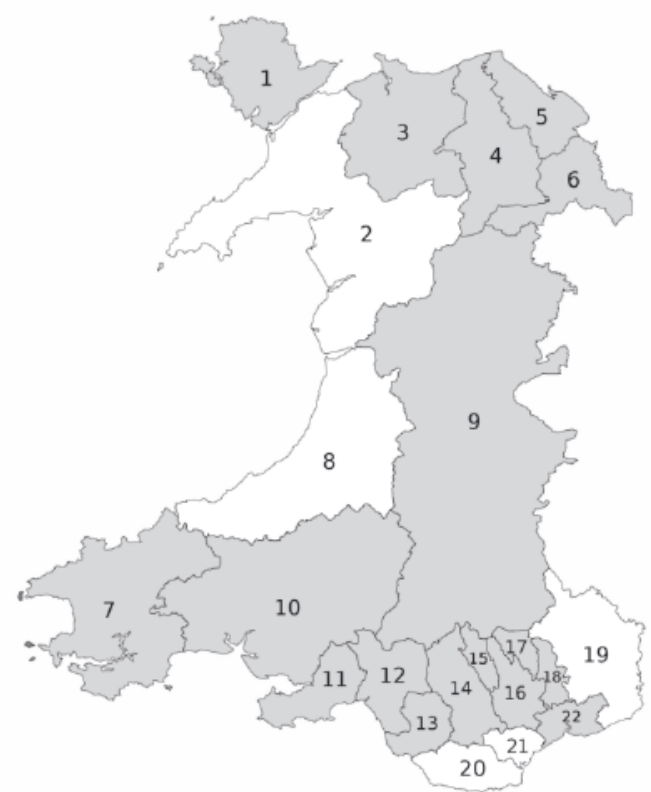

\section{Legenda}

$\square$ wysoki odsetek osób urodzonych w Anglii

niski odsetek osób urodzonych w Anglii

1- Isle of Anglesey
2-Gwynedd
3-Conwy
4- Denbighshire
5- Flintshire
6-Wrexham

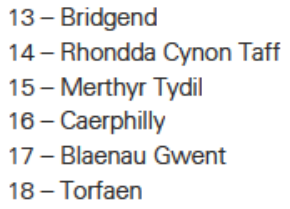

18 - Torfaen

19 - Monmouthshire

20 - Vale of Glamorgan

21 - Cardiff

22 - Newport

Żr ódło: Opracowanie własne na podstawie spisu powszechnego 2011 (ONS, 2012)

Walijczycy po raz pierwszy stanęli przed podobnym wyborem w 1975 roku, gdy decydowano o przystąpieniu Zjednoczonego Królestwa do istniejących jeszcze wówczas wspólnot europejskich. Jednak za przystąpieniem Zjednoczonego Królestwa opowiedziało się 64,8\% mieszkańców Walii, którzy wzięli udział w referendum (Mourlon-Druol, 2015).

Ponadto, dynamika zmian w preferencjach politycznych Walijczyków sprawia, że można je określić mianem niedokończonych, odwołując się do terminologii autorstwa Jacka Wodza. Jego koncepcja niedokończonych tożsamości narodowych zakłada bowiem, że ich przyczyną jest brak ciągłości państwowej charakterystyczny głównie dla państw Europy Środkowej i Wschodniej, w tym Polski. Ów brak ciągłości państwowej sprawit, że każde kolejne pokolenie wychowywało się w nieco odmiennych warunkach (Wódz, 2012). O niedokończonym charakterze tożsamości narodowych można mówić jednak również w przypadku Walii. 
Choć walijska tożsamość narodowa charakteryzuje się wyższym stopniem przewidywalności, to nie oznacza to jednak jej skończoności. Owa przewidywalność wynika bowiem gtównie z zapożyczeń, jakie są w niej obecne i pochodzą z brytyjskiej tożsamości narodowej. Nowe jej elementy zaczynają dopiero przybierać bardziej lub mniej wyraźny ksztatt i bardziej lub mniej identyfikowalną formę (Libor, 2016 ).

Równie istotnym wydarzeniem jak utrata państwowości przez państwa Europy Środkowej i Wschodniej był dla Walii rozpoczęty w latach 90 XX wieku proces dewolucji, którego początek okazał się jednym z ważniejszych momentów w historii Walii. Dewolucja to proces przekazania części kompetencji centralnych organów parlamentarnych instytucjom regionalnym lub też proces tworzenia niewybieralnych organów w ramach istniejącej już struktury administracji rządowej. Istnieje wiele teorii co do znaczenia tego procesu zarówno dla państwa, jak i społeczeństwa. Z punktu widzenia poruszanej w niniejszym artykule problematyki, za szczególnie istotną uznać należy teorię, wedle której dewolucja stanowić ma wyraz uznania odrębności tożsamościowej mniejszości etnicznej zamieszkującej określone terytorium, w omawianym przypadku Zjednoczone Królestwo. Tym też tłumaczyć można, przynajmniej po części, asymetryczność obowiązujących na jego terenie rozwiązań instytucjonalno-prawnych (MacKinnon, 2015). Zakres przyznanej swobody może być w związku z tym postrzegany jako wyznacznik uznawalności owej odrębności.

Socjalizacja dzisiejszego pokolenia Walijczyków odbywa się zatem w zupełnie innych niż przez lata warunkach.

Wyjaśnienia decyzji wyborczych podjętych przez mieszkańców Walii w czasie referendum na temat pozostania Zjednoczonego Królestwa w Unii Europejskiej nie można również upatrywać w wysokości wsparcia, jakie każdy z regionów otrzymał, albowiem na terenie Zachodniej Walii i Dolin spotkać można okręgi wyborcze, których mieszkańcy opowiedzieli się zarówno za pozostaniem Zjednoczonego Królestwa w Unii Europejskiej, jak i za opuszczeniem Unii.

\section{W POSZUKIWANIU WYJAŚNIENIA - MEDIATYZACJA KAMPANII POLITYCZNYCH}

Jednym z determinantów decyzji politycznych Walijczyków są bez wątpienia przekazy medialne. O wpływie mediów na podejmowane przez wyborców decyzje napisano już wiele (Dziadzia, 2007). Konkluzje płynące z większości z nich jedynie potwierdzają dobrze znane dziś i wciąż często spotykanie określenie mediów jako czwartej władzy, wprowadzone do obiegu przez Edmunda Burke'a. Również w przypadku referendum w sprawie opuszczenia Unii Europejskiej przez Zjednoczone Królestwo ten wpływ był nad wyraz znaczący i widoczny. Przeglądając komentarze brytyjskich, w tym walijskich komentatorów życia politycznego, dostrzec można, że wielu z nich podkreśla, jak ogromną rolę w procesie budowania atmosfery pro-wyjściowej odegrały właśnie media. Symbolem tego stał się plakat ‘Breaking Point' Partii Niepodległości Zjednoczonego Królestwa oraz jego treść 'We must break free of the EU and take back control of our borders' (Moore, 2017). Widok syryjskich imigrantów zmierzających do granic Unii Europejskiej, pomimo iż spotkał się z krytyką mediów, to krytyka ta dotyczyła przede wszystkim formy, a nie merytorycznej zawartości plakatu. Media stały się jedynie narzędziem wzmacniającym istniejące już negatywne emocje towarzyszące dyskusji na temat problemu imigracji w Walii, jak i w pozostałych częściach Królestwa. Tym samym dyskurs medialny towarzyszący referendum trafit na podatny grunt kampanii ksenofobicznej, jaka w tym samym czasie przetoczyła się przez całą Europę. Gdy- 
by referendum odbyło się w zgoła odmiennych warunkach, debata na jego temat mogłaby mieć zupełnie inny charakter, a samo referendum mogłoby zakończyć się innym wynikiem. Niewiele miejsca poświęcono bilansowi ewentualnych zysków i strat z opuszczenia Unii Europejskiej przez Zjednoczone Królestwa, w tym również przez Walię, której bilans, przynajmniej ten finansowy, nadal jest korzystny. Brak rzetelnej debaty na ten temat sprawił, że świadomość Walijczyków co do korzyści płynących z członkostwa w Unii Europejskiej ustępuje w praktyce miejsca emocjonalnej rozgrywce.

W wielu komentarzach na temat referendum w Walii zwraca się również uwagę na to, że jest ono sygnałem zmian, swoistym ostrzeżeniem dla Partii Pracy, która od momentu powstania Zgromadzenia Narodowego Walii oraz powołania pierwszego rządu walijskiego nieprzerwanie, samodzielnie lub też w koalicji z inną partią, sprawuje władzę w Walii (Toszek \& Kużelewska, 2011). Zdecydowana większość okręgów wyborczych opowiedziała się bowiem wbrew stanowisku rządu walijskiego. Referendum nie było zatem wydarzeniem oderwanym od wewnętrznej sytuacji Walii. Ogólne zniechęcenie do kierunku i tempa zmian zachodzących w Walii sprawiło, że referendum to mieszkańcy Walii postanowili wykorzystać, aby przypomnieć rządzącym o złożonych przez nich obietnicach wyborczych, a zarazem, jak niemal w każdych wyborach, dać wyraz swojemu niezadowoleniu z rządów Partii Konserwatywnej (O’Hagan, 2016).

\section{KONSEKWENCJE OPUSZCZENIA UNII EUROPEJSKIEJ PRZEZ WALIĘ}

Wynik referendum i stanowiąca jego pokłosie decyzja władz centralnych w Londynie o opuszczeniu struktur unijnych sprawiają, że równie istotne wydaje się pytanie o skutki tejże decyzji dla Walii i jej mieszkańców. Jedną z ciekawszych analiz jest opracowanie autorstwa Jo Hunt, Rachel Minto i Jayne Woolford pt. Winners and Losers: the EU Referendum Vote and its Consequences for Wales (Hunt, Minto, \& Woolford, 2016). Zwracają oni uwage na to, że decyzja o opuszczenia Unii Europejskiej przez Walię może okazać się dla samej Walii, jak i Walijczyków sporą szansą, choć okupioną, przynajmniej w początkowym okresie, sporymi kosztami. Szansa ta wynika przede wszystkim z faktu, że w związku z członkostwem w Unii Europejskiej, Zgromadzenie Narodowe Walii i rząd walijski otrzymały dodatkowe kompetencje w takich dziedzinach jak polityka rolna, środowiskowa czy też gospodarcza. Po opuszczeniu Unii Europejskiej powstanie zatem swoistego rodzaju 'pustka' instytucjonalno-prawna, która wymagać będzie pewnego rodzaju zagospodarowania. Do tej pory bowiem w wielu dziedzinach decyzje Unii realizowane były w formie dyrektyw, których implementacja dokonywana była przez każdy kraj członkowski z osobna, uwzględniając jego specyfikę. Część tych dyrektyw wdrażana była przez władze walijskie w sposób zupełnie inny niż czynią to władze brytyjskie. Część natomiast, z racji chociażby konieczności zachowania pewnej ogólnokrajowej spójności i logiki, narzucana była przez władze w Londynie. W rezultacie wraz z rozpoczęciem całej procedury wyjścia Zjednoczonego Królestwa z Unii Europejskiej władze walijskie mają do wyboru następujące scenariusze: całkowitą deregulację, modyfikację istniejącego prawa bądź też pozostawienie dotychczasowych rozwiązań prawnych.

W niektórych dziedzinach (np. w przypadku polityki energetycznej) fakt istnienia licznych powiązań pomiędzy poszczególnymi regionami sprawia, że władze walijskie nadal uzależnione będą w swych decyzjach od ustawodawstwa ogólnokrajowego. Walijczycy stanęli zatem po zwycięskiej stronie toczonego sporu i nie uczynili tego bezinteresownie, licząc przede wszystkim na korzyści dla siebie. 
Władze w Londynie będą zatem zmuszone do prowadzenia negocjacji nie tylko z Brukselą, ale również do negocjowania z Cardiff czy też Edynburgiem. Negocjacji, które nie będą łatwe, chociażby ze względu na odmienne barwy polityczne rządu walijskiego i rządu w Londynie. Tym bardziej że władze walijskie, opracowując dokument External Affairs and Additional Legislation Committee Implications for Wales of leaving the European Union or Wales of leaving the European Union, jasno wskazały te wymiary współpracy, których utrata budzi szczególne obawy. Zaliczono do nich między innymi: utratę dostępu do jednolitego rynku, ograniczenia w handlu produktami rolnymi, ograniczenie swobody przepływu osób, konieczność ponownego określenia statusu studentów i pracowników naukowych, obawy związane z marginalizacją polityki środowiskowej, a także utratą wsparcia w tym zakresie, ograniczenie dostępu do siły roboczej, zwłaszcza dla sektora zdrowia, potrzebę utrzymania dostępu do badań medycznych i kontaktu z Europejską Agencją Leków, intensyfikacji działań na rzecz ograniczenia aktów ksenofobii, które nasility się jeszcze bardziej w okresie samego referendum, a także konieczność poradzenia sobie z ewentualną utratą finansowania ze strony Europejskiego Banku Inwestycyjnego oraz z innych źródeł (External Affairs and Additional Legislation Committee, 2017).

Brexit postrzegany jest zatem zarówno jako szansa na wzmocnienie kompetencji i pozycji rządu walijskiego i Zgromadzenia Narodowego Walii, jak i zagrożenie dla gospodarki walijskiej, czego dowodem jest lista obaw. Skutki wyjścia Zjednoczonego Królestwa z Unii Europejskiej warto również rozpatrywać z punktu widzenia procesu kształtowania się tożsamości narodowej Walijczyków. Być może jesteśmy dziś bowiem świadkami tworzenia się w społeczeństwie walijskim zupełnie nowych podziałów socjo-politycznych, których potwierdzenie wymagać będzie analizy wyników zbliżających się wyborów parlamentarnych i samorządowych. Pytanie brzmi bowiem, na ile preferencje co do kwestii pozostania w Unii Europejskiej lub też jej opuszczenia znajdą wyraz w przyszłych decyzjach wyborczych mieszkańców Walii. Odwołując się w tym miejscu ponownie do koncepcji niedokończonych tożsamości społecznych, uzyskanie odpowiedzi na to pytanie pozwoliłoby z pewnością określić, na ile preferencje polityczne Walijczyków uznać można za stabilne, a na ile podlegają dalszym zmianom. Opuszczenie Unii Europejskiej bez wątpienia będzie miało wpływ na to, kim są i w jaki sposób postrzegają siebie mieszkańcy Walii. Jeśli przyjąć, że decyzje wyborcze Walijczyków podyktowane były w większości przypadków negatywnym przekazem medialnym, a więc raczej subiektywnym odczuciem, a nie obiektywnymi przesłankami, wówczas możemy mieć do czynienia ze zjawiskiem określanym w psychologii społecznej mianem dysonansu poznawczego. W takim przypadku możliwe są dwa scenariusze kształtowania się preferencji politycznych mieszkańców Walii w najbliższej przyszłości. Próba poradzenia sobie z dysonansem poznawczym jako takim może bowiem zaowocować bądź powrotem nastrojów proeuropejskich, a zatem chęcią pozostania w Unii Europejskiej, mimo wyniku referendum, bądź też utrwaleniem postaw antyeuropejskich tj. utwierdzeniem się w dokonanym wyborze, choć nie zawsze słusznym.

\section{ZAKOŃCZENIE}

Na ocenę skutków decyzji władz brytyjskich o opuszczeniu Unii Europejskiej z pewnością przyjdzie nam jeszcze poczekać, tym bardziej że sam proces nie został ukończony. Niemniej jednak już dziś można pokusić się o kilka wniosków i przedstawić kilka scenariuszy dalszego rozwoju sytuacji. 
W powyższym artykule skupiono się przede wszystkim na preferencjach politycznych mieszkańców Walii, których wyrazem stał się udział w referendum, do którego doszło 23 czerwca 2016 roku, a które zakończyło się zwycięstwem zwolenników brexitu. Użyteczność koncepcji tożsamościowych, którymi posłużono się celem wyjaśnienia wyników referendum okazała się jednak niewystarczająca. Za ich pomocą wyjaśnić można kilka przypadków, lecz nie wszystkie. O wiele trafniejsza wydaje się koncepcja tożsamości G. Daya, dla którego tożsamość narodowa Walijczyków stanowi wypadkową wielu czynników, nie tylko miejsca urodzenia czy też znajomości języka. Wśród tych czynników należałoby również wspomnieć o negatywnym wpływie mediów, a zwłaszcza o tym, w jaki sposób zostały one wykorzystane do stworzenia atmosfery niepokoju oraz strachu. Zabrakło miejsca na w pełni merytoryczną debatę na temat tego, jakie korzyści oraz zagrożenia niesie ze sobą dalsze członkostwo w Unii Europejskiej. Brexit postrzegany jest dziś w Walii jako szansa jedynie w kategoriach czysto politycznych, jako szansa wzmocnienia kompetencji oraz pozycji zarówno rządu walijskiego, jak i Zgromadzenia Narodowego Walii. Równocześnie jednak sporym wyzwaniem dla władz walijskich będzie konieczność poradzenia sobie z brakiem lub też ograniczeniem środków z Unii Europejskiej. Formą rekompensaty za utracone środki miałoby być zwiększenie dotacji otrzymywanej przez władze walijskie z budżetu centralnego. Brexit oznacza zatem nie tylko negocjacje między Brukselą a Londynem, ale również między Londynem a Cardiff, które chociażby ze względu na odmienne barwy polityczne obu rządów będą niezwykle interesujące. Testem ich efektywności okaże się z pewnością głosowanie nad przyjęciem finalnej wersji ustawy dotyczącej wyjścia Zjednoczonego Królestwa z Unii Europejskiej. Wówczas dowiemy się, jak dalece warunki zaproponowane przez Partię Konserwatywną były dla rządu Partii Pracy atrakcyjne i do jakiego stopnia akceptowalne.

\section{BIBLIOGRAFIA}

Babbie, E. (2008). Podstawy badań społecznych (W. Betkiewicz, Tłum.). Warszawa: Wyd. Naukowe PWN.

Day, G. (2002). Making sense of Wales; A sociological perspective. University of Wales Press, Cardiff: University of Wales Press.

Dziadzia, B. (2007). Wpływ mediów; Konteksty społeczno-edukacyjne, Kraków: Oficyna Wydawnicza Impuls.

External Affairs and Additional Legislation Committee. (2017). Implications for Wales of leaving the European Union. Pobrano 12 czerwca 2018, z http://powys.moderngov.co.uk/documents/s15139/Implications \% 20for\%20Wales \%20of\%20leaving \% 20 the \%20EU\%20Eng.pdf

Hunt, J., Minto, R., \& Woolford, J. (2016). Winners and losers: the EU referendum vote and its consequences for Wales. Journal of Contemporary European Research, 12(4), 824-834.

Libor, G. (2016). Walijska tożsamość narodowa a koncepcja niedokończonych tożsamości Jacka Wodza. W T. Nawrocki \& W. Świątkiewicz, Ład społeczny i jego przedstawienia; Ksiega jubileuszowa Profesora Jacka Wodza. Katowice: Wyd. UŚ.

Loughlin, J. (2007). The Welsh case: Cultural diversity of a nation with devolved powers in a unitary state. W D. Smith \& E. Wistrich, Regional identity and diversity in Europe (ss. 35-63). London: Federal Trust. 
MacKinnon, D. (2015). Devolution, state restructuring and policy divergence in the UK. The Geographical Journal, 181(1), 47-56. https://doi.org/10.1111/geoj.12057

Moore, K. (2017). Wales, immigration, news media and Brexit. Pobrano 10 czerwca 2018, z http://www.referendumanalysis.eu/eu-referendum-analysis-2016/section-2-politics/walesimmigration-news-media-and-brexit/

Mourlon-Druol, E. (2015). The UK's EU Vote: The 1975 precedent and today's negotiations, Bruegel Policy Contribution, 2015(8).

O'Hagan, E. (2016). Wales voted for Brexit because it has been ignored by Westminster for too long. Pobrano 10 czerwca 2018, z http://www.independent.co.uk/voices/brexitwales-eu-referendum-vote-leave-uk-ignored-by-westminster-a7102551.html

ONS. (2012). 2011 Census: Key statistics for Wales, March 2011. Pobrano 10 czerwca 2018, z https://www.ons.gov.uk/peoplepopulationandcommunity/populationandmigration/populationestimates/bulletins/2011censuskeystatisticsforwales/2012-12-11

Rhys, S. (2017). This is how much money Wales gets from the European Union and how it is spent. Pobrano 10 czerwca 2018, z https://www.walesonline.co.uk/news/politics/ how-much-money-wales-gets-12765100

The Electoral Commission. (2017). EU referendum results. Pobrano 10 czerwca 2018, z https://www.electoralcommission.org.uk/find-information-by-subject/elections-andreferendums/past-elections-and-referendums/eu-referendum/electorate-and-countinformation

Toszek, B., \& Kużelewska, E. (2011). Od wizji do rzeczywistości; Dziesięć lat dewolucji w Walii. Warszawa: Oficyna Wydawnicza ASPRA JR.

Williamson, D. (2014). EU funding for Wales: The fact that Wales' poorest communities still qualify for billions is an 'indictment' of the Welsh Government's failure, it is claimed. Pobrano 10 czerwca 2018, z https://www.walesonline.co.uk/news/wales-news/fact-walespoorest-communities-still-8022249

Wódz, J. (2012). Tak zwane niedokończone tożsamości narodowe w krajach Europy Środkowej i Wschodniej: Krótki esej z antropologii polityki. W E. Bogacz-Wojtanowska, W. Gumula \& S. Rębisz, S., Zróżnicowanie i zmienność społecznego świata (ksiega jubileuszowa poświęcona Kazimierzowi Z. Sowie) (ss. 183-197). Kraków: Wydawnictwo Uniwersytetu Jagiellońskiego. 